\title{
当教室におけろ口益形成術とその言語成維（1973．3～1975．9）
}

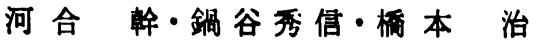 \\ 栗田贤一・池田密昭・内山 微* \\ 服部美知恵*・下岡美智子”*
}

\section{Speech results after cleft palate repair at our institute from March 1973 to September 1975}

\author{
Tsuyoshi Kawai • Hidenobu Nabetani - Osamu Hashimoto \\ Kenichi Kurita - Noriaki Ikeda - Miru Uchiyama* \\ Michie Hattori* - Michiko ShimookA*
}

\begin{abstract}
: 109 cases with the cleft palate operated primarily by the push-back method at our institute from March, 1973 to September, 1975 were investigated for speech condition.

The sufficient velopharyngeal function, slight hypernasality, and hypernasality were observed in 85 cases $(78.0 \%), 20$ cases $(18.3 \%)$ and 4 cases $(3.7 \%)$, respectively.

In view of cleft types, sufficient velopharyngeal functions were obtained in 29 out of 32 cases $(90.6 \%)$ in the isolated cleft palate group, 39 out of 45 cases $(86.7 \%)$ in the unilateral cleft lip and palate group, and 17 out of 32 cases (53.1\%) in the bilateral cleft lip and palate group. Then, in a case of the submucous cleft palate, hypernasality wasn't observed.

Palatalized articulation accounted for 47 cases of the total 109 cases of abnormal articulation $(43.1 \%)$, followed by glottal stops in 8 cases $(7.3 \%)$ and nasal articulation in 4 cases (3.7\%).
\end{abstract}

Key words: cleft palate, palatoplasty, speech results

緒

口蓋裂手術の主目的は，披裂部の閉鎖と良好な咽腔 閉鎖機能を営み5る口蓋を形成し患者に正常な言語を獾 得させることにある。.これらの目的のため，先人達の努 牲より種々の手術方法 ${ }^{1 \sim 7}$ ) や追跡調査 ${ }^{8 \sim 12)}$ 等が発表さ れ，今日の口蓋弁後方移動術の全盛をみるにいたってい

要知学院大学齿学部第 2 口腔外外学救室

（主任：河合 幹教授）

* 愛知学院大学齿学部附属病院言語治室室

The second department of Oro-Maxillo-Facial Surgery, School of Dentistry Aichi-gakuin University (Chief: Prof. Tsuyoshi Kawai)

* Speech Laboratory Clinic, School of Dentistry, Aichi-gakuin University

受付日：昭和59年11月19日
る.さらに全身麻醉の進歩により乳幼児手術の安全性が 高まり，口蓋裂手術も患児が言語を獾得する前の早期手 術を施行することが容易になったので術後の言語成䋖る

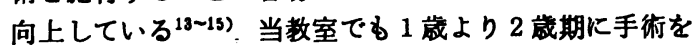
施行し良好な結果を得ているので, 昭和48年 3 月より 2 年半の間に手術を施行し 7〜10年後の言語成績を確認し 得ている口蓋裂患者109名について娭討を加え報告する.

\section{症例について}

対象は, 昭和48年 3 月より昭和50年 9 月までの 2 年 6 か月間に当教室で口蓋裂初回手術を口蓋弁後方移動術に よって行った患児 109 例〔唇・䅡・口蓋裂群77例（70.6 $\%)$, 口蓋裂単独群32例 $(29.4 \%)$, 唇・類・口蓋裂群の $5 ち$ 片側裂群が 45 例 (全体の $41.2 \%$ ), 両側裂群が32例 (29.4\%) で口蓋裂単独群のらち粘膜下裂 1 例を含む] であった。 


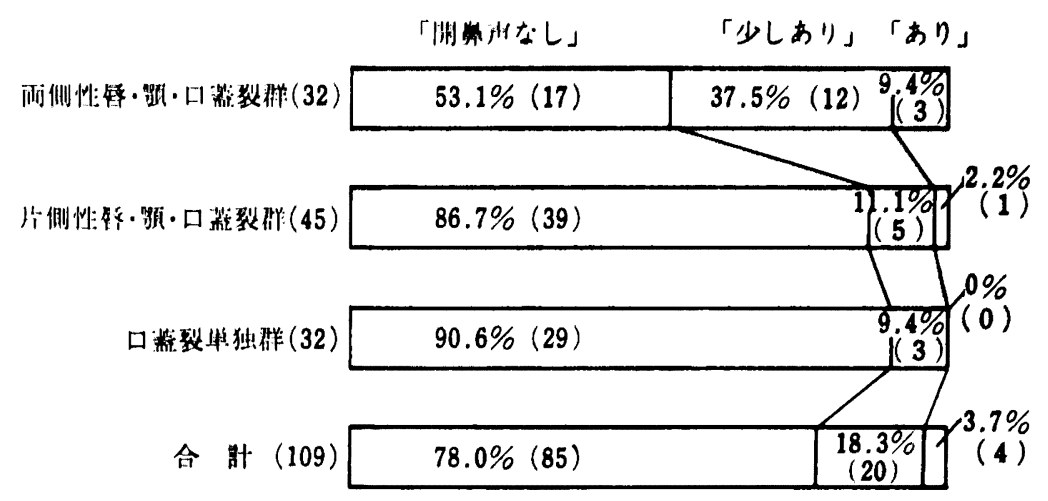

图 1 覑の判定秙果

\section{手術年㙮について}

口盖裂手術の施行年齢は，䇾語発達と影発育を考虑し

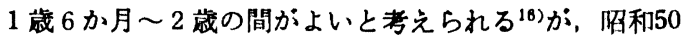
年以前においては当教室ではやや早い1歳 1 か月から 1 歳 7 か月頃までの期間に口蓋裂手術を行った症例が多か った，表 1 に示すごとく，平均手術施行時期は 1 歳 3.7 か月であった。

\section{手 術 方 法}

当時の当数室における手術法は，下記のごとくであっ た。蓋弁後方移動術，3) の通法に従い，披裂緑之齿頸

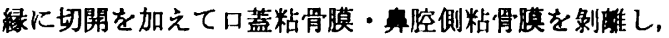
番腔側粘骨膜においては便・㳄口蓋移行部付近でZ形成 術を加え，口腔側・鼻腔側とも口蓋全体を後方移動さ せ，口蓋帆举筋は硬口蓋後縁より切離するが，その方向 は特に変えることなく， side to side の形で側縁を相互 に琏合する方法によっていた。

翼突鉤の処理については，全例これを折損して口蓋帆 張筋の減張を実施し，術後にセルロイドシーネと印象用 コンハ・ウンドを併用した口蓋挙上を実施した。

\section{手術成績の判定について（言語面より）}

口蓋裂患者の言語障害は，開声と異常構音より成立 しているが，今回の調查では言語治療士の㯰覚的判定を 主として下記の基準により判定した。

\section{1）咽腔閉鎖機能不全による開辛声の程度}

会話音声の聴覚印象により，「開奥声なし」，「少しあ り」「「り」の 3 段階にわけた.

2 ）異常構音の有無

下記のごとき 6 種の異常構音の有無につき調査した.

・声門破裂音 (glottal stop)
夜 1 口篮手衙時期について

\begin{tabular}{|c|c|}
\hline 1 散 0 か月〜 1 名月末海 & 0保 \\
\hline 1 か月〜 2 か月末葓 & 16侈 \\
\hline 2 か月〜 3 か月末满 & 25体 \\
\hline 3 か月〜 4か月末渾 & 18湖 \\
\hline 4 か月〜 5 か月末菹 & 19隹 \\
\hline 5 か月〜 6 か月末溚 & 12保 \\
\hline 6 か月〜 7 か月末洗 & 5何 \\
\hline 7 か月〜 8 か月末满 & 2何 \\
\hline 8 か月〜9か月末满 & 5 例 \\
\hline 9 か月～10か月末愺 & 3例 \\
\hline 10か月〜11か月末满 & 3保 \\
\hline 11か月〜12か月末满 & 1例 \\
\hline 合 部 & 109何 \\
\hline
\end{tabular}

- 咽頭庶擦音 (pharyngeal fricative)

- 咽頭破裂音 (pharyngeal stop)

-口蓋化構音 (palatalized articulation)

- 側音化棈音 (lateral articulation)

- 算腔檍 (nasal articulation)

$$
\text { 结果 }
$$

\section{1. 咽腔閉銧機能不全による開声の程度} 判定結果は图 1 に示すことくである。「開悬声なし」 は85例で78.0\%,「少しあり」は20例で18.3\%,「あり」 は 4 例で $3.7 \%$ であった。

裂型別にみると口蓋裂単独群が一番成樍よく90.6\%が 「開声なし」，9.4\%が「少しあり」「「あり」は0\%で あった。 ついで片側性唇・䫑・蓋裂群で， $86.7 \%$ が 「開声なし」，11.1\%が「少しあり」「「り」は2.2\% であった。両側性唇・影・口蓋裂群が一番成樍悪く， 


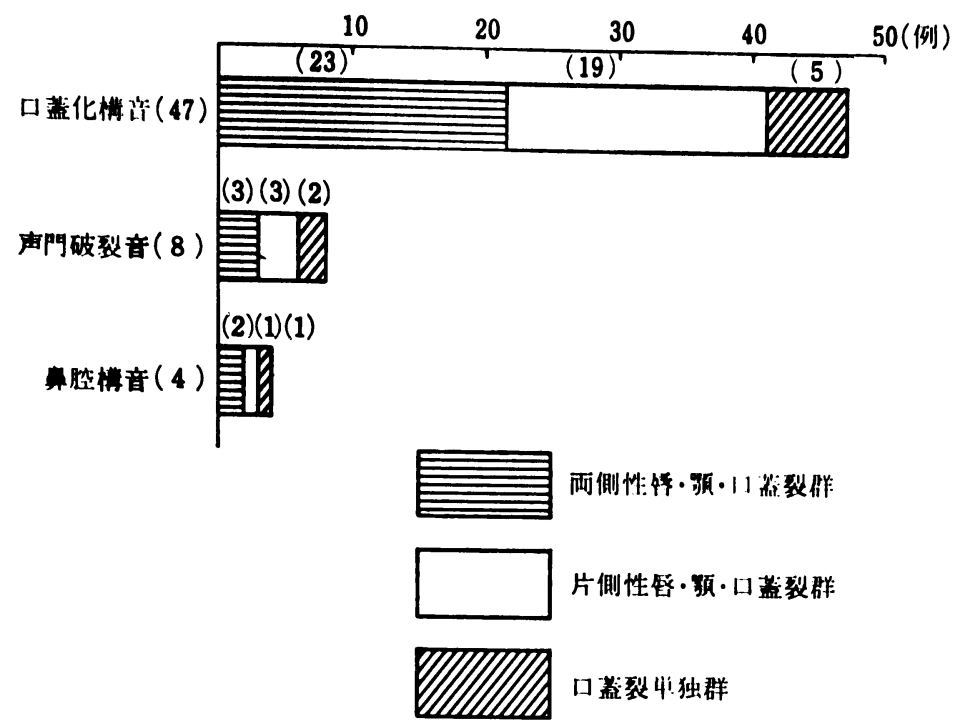

图 2 具常構音の判定結果

53.1\%が開声なし」，37.5\%が「少しあり」，9.4\% が「ありであった.

男・女別にみると，男児（58例）では 47 例 $81.0 \%$ が 「開声なし」，8例13.8\%が「少しあり」「「あ」が 3 例5.2\%，女览 (51例) では39例76.5\%か；開声なし」， 11例21.6\%が「少しあり」，1 例1.9\%が「あり」で，著 明な差は認めなかった。

\section{2. 異常棒音の判定結果}

異常檍音のうちで口蓋化構音が一番多く, 109 例中 47 例(43.1\%) に認められた，裂型別にみると，両側性唇・ 穎・口蓋裂群23例, 片側性唇・額・口蓋裂群19例, 口蓋 裂単独群 5 例であった.

声門破裂音は 8 例 (7.3\%) に認められ, 両側性唐・ 穎・蓋裂群 3 例, 片側性唇・額 - 口蓋裂群 3 例, 口蓋 裂単独群 2 例であった。

㫷腔構音は 4 例 (3.7\%) 飞認められ，両側性唇・䫅・ 口蓋裂群 2 例, 片側性唇 - 顎 - 口蓋裂群 1 例, 口蓋裂単 独群 1 例であった. なお，今回の調査では咽頭摩摖音・ 咽頭破裂音・側音化構音は認められなかった（図 2 ）。

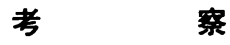

口蓋裂について以前より, 口蓋裂の発生 ${ }^{17)}$, 手術方法 の開発 ${ }^{1 \sim, 18)}$, その手術か顎発育に及ぼす影謷 ${ }^{8 \sim 11)}$, 言語 学的な研究5 7,13 15,18) など種々の報告がなされている. いずれの報告す披裂部の閉鎖，良好な策咽腔閉鎖機能の 付与の必要性を強調し，いかにそれを果すかといら点に 先人事の努力がなされてきた。

口蓋裂患者に特有に認められる開兵声は, 発声時に軟
口蓋の後悢が咽頭後壁に接触しないことにより出現す る.それを改普するために今日では口蓋弁後方移䖝術に よりその障害を回淇しようと企て，さらに muscle sling の形成を得ようと努力がなされている．昭和49年頃われ われは，確実な口蓋弁後方移動とその結果を一百確実に するための鼻腔側粘膜の Z 形成術を施行, 馀突銁折損に よる確実な減張，口蓋帆挙能をはじめとする軟口蓋諸筋 の確実な栰合(昭和 48〜50 年当時は筋側緑相互の程合), 手術直後のセルロイドシーネとコンパウンドによる軟口

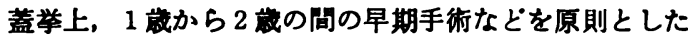
手術を施行していた.

言語成績判定に咸しては，客観的にこれを解析する手 段が種々考案されつつあるが19 22)，これを実際面にどう 活用できるか困難を感じる場合が多く，今回われわれは あえて言語治療士の聴覚判断という取も実用的な基萡に よる手術成績をとりあげた。

言語成紸に関する報告は各施設より発表されている が, 成判定時期・判定基準・術後言語治療の有無など 一定ではない，そのため，単独に比较検討することは困

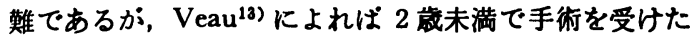
ものの 70\%, Lindsay ${ }^{14)}$ によれば 3 歳末満で手術を受け

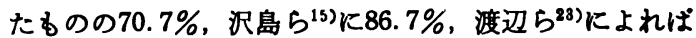
$67 \%$ ，辻ら24によれば65.3\%が正常言語を獾得したと報

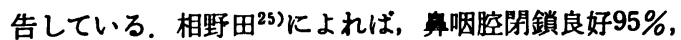
異常構音あり $46 \%$ と共鳴異常 (開鼻声) に関する評価と 語音のつくり方の異常（異常楧音）に関する評価を分け て報告している. われわれる同様に調査した結果「開 声なし」78.0\%，「少しあり」18.3\% と全体の $96.3 \%$ が再手術の必要のない者であった，裂型別に開臭声の程 


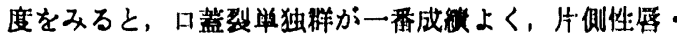

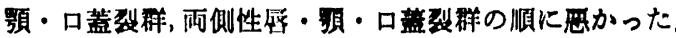
吉岡 ${ }^{20)}$ の報告では，片侧裂上り西側裂の方が良好と述べ

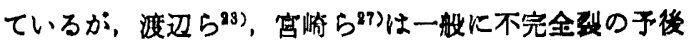

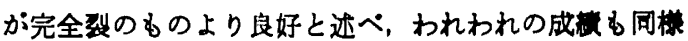
の結果であった。この原因は，不完全裂より完全裂，片 侧裂より雨侧裂の方が一般に披裂幅が広く口㦈組倳是が

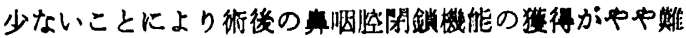
しくなると推察される。

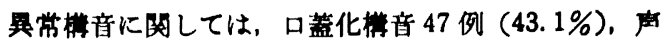
門破裂音 8 例 (7.3\%)，其腔棈音 4 例 (3.7\%) と口篮 化樈音が一番多く㮣められたか，他の報告では79\%

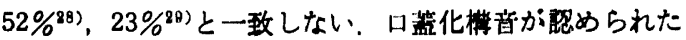
症例と裂型別にみると，再侧裂 23/34 例，片側裂 19/43 例，口蓋裂単独 $5 / 31$ 例と裂型との闺連性が示唆され，岡 䗁 ${ }^{30}$ の口䒸化構音の発現は裂型と関連があったとの報告 と一致している。

今回の調査の全体の印象として，良好な算咽腔閉鎖機 能が得られても口蓋化橉音, 声門破裂音といった異常棈 音の残存する症例も多くみられ，手術法の一層の改良・ 言語訓練の改良などの必要性を痛感せしめた。

今後これ以降に実施している口蓋帆举筋の遊㠎とその 端々䊕合による成紸を追求し，今回の成績との比較を行 いたいと考えている。

\section{結語}

われわれは，昭和48年 3 月より昭和 50 年 9 月までの 2 年 6 か月間に当教室で施行した初回口蓋裂手術について 言語成績を発表した。この時期の手術は，硬口蓋粘膜骨 膜弁举上，翼突鈎折損による確実な堿張，鼻腔側 Z 形成 術を加えた口蓋弁後方移動，口蓋帆挙筋をはじめとする 軟口蓋諸筋の side to side の䋖合, 術直後のシーネによ る軟口蓋挙上などを行っていたが，開重声もなく十分な 兵咽腔閉鎖機能を得たものは78.0\%であった。

\section{引用 文 献}

1) Dorrancc, G.M.: The push-back operation for repair of cleft palate. Plast Reconstr Surg 1: 145-169 1946.

2) Conway, H.: Combined use of the push-back and pharyngeal flap procedures in the management of complicated cases of cleft palate. Oral surg 5: 133-142 1952.

3) Cronin, T.D.: Method of preventing raw area on nasal surface of soft palate in push-back surgery. Plast Reconstr Surg 20: 474-484 1957.

4) Millard, D.R.: The island flap in cleft palate surgery. Surg Gynecol Obstet 116: 297-300 1963.

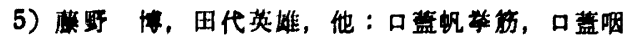

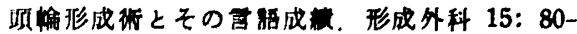
811972.

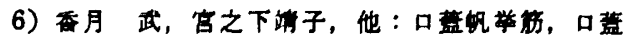

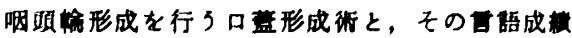

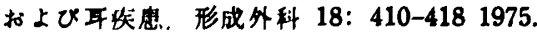

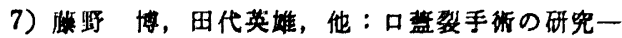

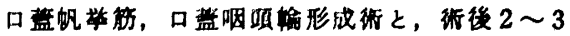

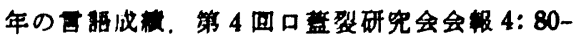
811974.

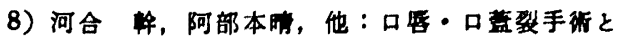

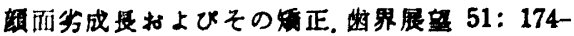
1761974.

9）柴崎好伸：䂆発高. 形成外科 22: 241-246 1979.

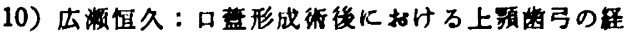

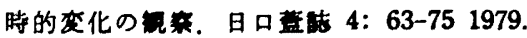

11）立松 充：口者・口篮裂の披裂形態とその形成

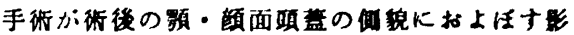
雷について。目に蓝誌 5: 1-8 1980.

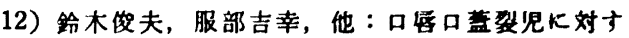
る地城社会の認識について。日口蓝誌 4:63751979.

13) Veau, V.: Division palatine: anatomie, chirgie, phonetique. Masson et Cie, Paris, 1931, 1-35. 27）上り引用.

14) Lindsay, W.K., LeMesurier, A.B., et al.: A study of the speech results of a large series of cleft palate patient. Plast Reconstr Surg 29: 274-288 1962.

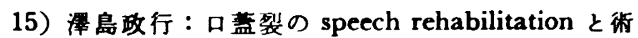
後の言語機能。日耳 64：563-565 1961.

16）上石 弘，伊藤正豩，他：口盖裂の手術。歯科 ジャーナル 7: 173-181 1978.

17）饭塚忠彦: 顔面と口腔の発生一上口㕆, 口蓋の 発生時期を中心として一。形成外科 22: 2332401979.

18）香月武, 宮之下靖子, 他 : Primary Veloplasty

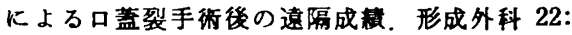
163-174 1979 .

19）日比野進：日本語構音に関する「レ」線的研究

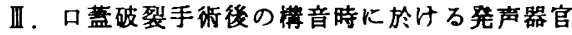
並に所謂附属管腔の系絠的観察. 阪大㐘学誌 1: 216-243 1956.

20) Wildman, A.J.: The role of the soft palate in cleft palate speech. Angle Orthod 28: 79-86 1958.

21）成毛二郎：頭部 $\mathbf{X}$ 線規格写真による得後口盖裂 患者の言語障害に関する研究，菌科学報 67: 180-221 1967.

22) Rossa, D.L., Brown, A. et al.: Video-Radiography of the Velopharyngeal Portal Using the Town's View. J Maxillofac Surg 8: 2032051980. 


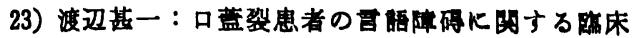
的研究。科学報 63：141-166 1963.

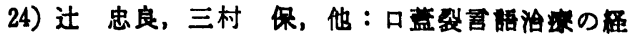

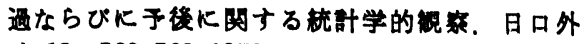
誌 18: 560-563 1972.

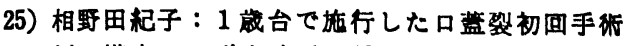
例の檍音。日形会誌 1：49-63 1981.

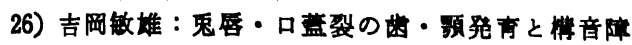

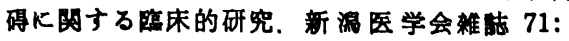
22-48 1957.

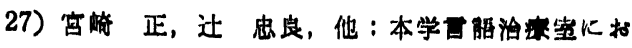

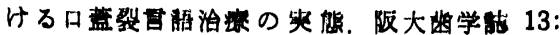
297-304 1968.

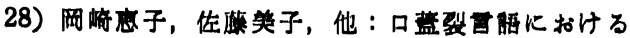

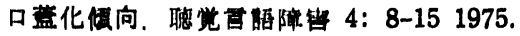

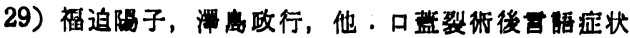

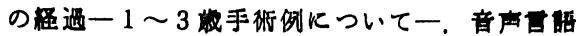
15: 37-46 1974.

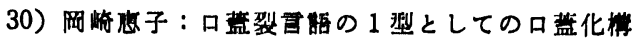
音. 日形会孰 2：164-176 1982. 